\title{
LOANS TO CLIENTS FOR LIVING EXPENSES
}

Many attorneys lend money for living expenses to destitute clients whom they represent in personal injury litigation. ${ }^{1}$ While a contingent fee contract allows an impoverished chent to obtain counsel, ${ }^{2}$ a loan to cover personal expenses may be necessary to sustain him during what often is a substantial time interval before trial. ${ }^{3}$ Such a loan may enable a client to pursue his claim fully by resisting inadequate settlement offers he might otherwise accept out of necessity. ${ }^{4}$

The legal profession is divided, however, over the ethics of lending money to clients for living expenses. ${ }^{5}$ Moreover, it is unclear whether the American Bar Association's Canons of Professional Ethics, ${ }^{6}$ which pres-

1 See D. Louisell \& H. Whelazis, The Parenchyma of Law 362 (1960); F. MacKnnNon, Contrngent FeEs for Legal Services 68 (1964). An indication of the prevalence of this practice is found in a recent tax case, Burnett v. Commissioner, 356 F.2d 755 (5th Cir.), cert. denied, 385 U.S. 832 (1966). In the course of deciding that an attorney may not deduct loans for living expenses to personal injury clients as a business expense when repayment is virtually certain, the court observed that it was apparently the "custom" among Texas attorneys representing personal injury plaintiffs to make such loans. $I d$. at 757 .

The author's conversations with a number of San Francisco Bay Area attorneys, who expressed the belief that loans were rarely inade in that area, suggest that the practice varies significanty with the locality.

2 A contingent fee is an attorney's fee consisting of or measured by a specified share of the client's recovery. F. MACKmwon, supra note 1 , at 39, 198. The distinguishing characteristic of the contingent fee arrangement is that if his client fails to recover, the lawyer is not entitled to a fee; it is payable only if some recovery is achieved through the lawyer's efforts. Id. at 3 . The contingent fee "makes possible the enforcement of legitimate claims which otherwise would be abandoned because of the poverty of the claimants." Radin, Contingent Fees in California, 28 CarIF. L. REv. 587, 589 (1940).

Most countries do not permit the use of contingent fee contracts. Comment, Are Contingent Fees Ethical Where Client is Able to Pay a Retainer, 20 O\#10 Sт. L.J. 329, 336 (1959); F. MACKINNON, supra note 1, at 209. However, in the United States "the contingent fee is the dommant system . . . by which legal services are financed by those seeking to assert a claim." Id. at 4 . Such a contract is legal today in all 50 states. Special Subcommittee of the Defense Research Committee of the International Association of Insurance Counsel, A Study of Contingent Fees in the Prosecution of Personal Injury Claims, 33 INs. Counser J. 197, 200 (1966).

This Comment discusses loans for living expenses in the context of continued widespread use and acceptance of the contingent fee. No consideration is given to proposed alternative means of financing suits by indigent claimants such as prepaid legal insurance. For a discussion, see F. MacKnNoN, supra note 1, at 4, 149-50. Such insurance of course could provide for payment of an indigent client's litigation expenses and litigation-related living expenses as well as his attorney's fees.

3 See F. Macknnon, supra note 1 , at 68.

${ }^{4}$ See text accompanying notes 74-81 infra.

5 F. Macknnon, supra note 1, at 206. San Francisco Bay Area attorneys, primarily specialists in personal injury claims, expressed in conversations with the author sharp differences of opinion on whether such loans should be permitted.

- The American Bar Association's Canons of Professional Ethics are published in H. 
ently govern the conduct of most attorneys in the United States, ${ }^{7}$ sanction such loans.

In 1955, the Legal Ethics Committee of the American Bar Association issued advisory Opimion $288^{8}$ which rejected a "settled course" of court decisions upholding loans for living expenses. Although several courts have not adopted the Legal Ethics Committee's view that all such loans are improper, ${ }^{10}$ at least two have. ${ }^{11}$ These conflicting decisions, and the dilemma they pose for attorneys in states whose courts have not confronted the issue, illustrate the need for reconsideration of the rules of professional ethics as they pertain to loans for living expenses. The

DrINRER, Legat EtBrics 309-25 (1953). Throughout the text these Canons will be referred to simply as "the Canons" and individual Canons will be referred to as "Canon - ?"

7 Many state bar associations have adopted the Canons of Professional Ethics. H. DRINKER, supra note 6, at 25 (1953). The highest courts of some states have adopted the Canons as rules of court. E.g., Mo. SUP. CT. R. 4 (1966). In the state of Washington, the Canons have been enacted by the state legislature. WASE. REv. CoDE ANN. $\S 2.48 .230$ (1961). The State Bar of California has promulgated its own Rules of Professional Conduct but the American Bar Association's Canons are "commended" to the nnembers of the State Bar for matters not covered by the Rules. Rules of Professionat Conduct of tee State Bar of Catifornta No. 1, 52 Cal. 2d 893 (1959).

The courts have inherent power to regulate the practice of law. People ex rel. Chicago Bar Assn' v. Goodman, 366 TIl. 346, 8 N.E.2d 941, cert. denied, 302 U.S. 728 (1937); In re Baker, 8 N.J. 321, 334-35, 85 A.2d 505, 511-12 (1951); Richmond Ass'n of Credit Men v. Bar Ass'n, 167 Va. 327, 335-36, 189 S.E. 153, 157 (1937). See generally Dowling, The Inherent Power of the Judiciary, 21 A.B.A.J. 635 (1935); Comment, 28 U. CEr. L. REv. 162 (1960). This includes the power to discipline attorneys for professional misconduct. Barton v. State Bar, 209 Cal. 677, 289 P. 818 (1930); In re Keenan, 310 Mass. 166, 37 N.E.2d 516 (1941). As adopted by state bar associations, the Canons have no statutory force. Herman v. Acheson, 108 F. Supp. 723, 726 (D.C. Cir. 1952); In re Cohen, 261 Mass. 484, 487, 159 N.E. 495, 496 (1928); In re MacDonald, 204 Minn. 61, 71, 282 N.W. 677, 682 (1938). However, the courts regard them as reflecting the attitudes of the profession and discipline attorneys for violating their provisions. People ex rel. Chicago Bar Ass'n v. McCallum, 341 III. 578, 589-90, 173 N.E. 827, 831 (1930); In re Cohen, supra. In some states, the discipline that may be imposed for professionally unethical conduct is limited to something less than disbarment. E.g., in California an attorney may be disbarred only for violation of statutorily enumerated offenses. CAT. Bus. \& Prof. Code \& 6078 (West 1962). The Board of Governors of the State Bar of California may only recommend suspension for up to three years for violation of the Rules of Professional Conduct. Id. § 6077.

8 ABA Comas. on Professionat Ethrcs, Opinions, No. 288 (1954), printed in 41 A.B.A.J. 33 (1955) [hereinafter cited as OpInIon 288.] The American Bar Association Committee on Professional Ethics is referred to in the text by its more common designation, "the Legal Ethics Committee." Opinions of the legal ethics committees of the American Bar Association and of state and local bar associations are issued in response to inquiries from attorneys and are purely advisory. Cheatham \& Lewis, Committees on Legal Ethics, 24 Carrr. L. REv. 28, 30, 32 (1935) ; H. DRnNEER, supra note 6, at 30-32.

9 Ratner, Advancing Money to Clients-Whether Unethical, 15 NACCA L.J. 410, 413 (1955) (criticizing OPINION 288, supra note 8).

10 See cases cited in notes 45-46 infra and accompanying text.

11 See cases cited in notes 47-48 infra and accompanying text. 
American Bar Association could clarify its position by including in the new Code of Professional Responsibility, scheduled for adoption in $1968,{ }^{12}$ a rule dealing exphicitly with such loans. This code will replace the admittedly outdated Canons of Professional Ethics, ${ }^{13}$ most of whiclr were originally promulgated in $1908 .^{14}$

This Comment recommends for adoption by the American Bar Association a rule which, in specified circumstances, would allow loans for living expenses. The writer believes that the proposed rule, set forth in the Conclusion, strikes a reasonable balance among the factors militating for and against the bar's endorsement of loanmaking by its members. This belief is based upon a consideration of court decisions concerming loans for hiving expenses and upon an analysis of the relevant issues.

I

\section{CONFLICTING COURT DECISIONS}

\section{A. Decisions before Opinion 288}

Prior to 1955 , the relatively few cases concerning the propriety of loans for living expenses produced a reasonably clear and consistent rule. ${ }^{15}$ According to these cases, an attorney acts improperly only if he offers money to a potential client as an inducement for employment ${ }^{16}$ or if he agrees to release the client from liability for repayment in case there is no recovery. ${ }^{17}$ Otherwise, the courts favored loans for hiving expenses,

12 Letter from Edward L. Wright, Chairman of the Special Committee on Evaluation of Ethical Standards of the American Bar Association, to W. R. Strelow, Sept. 26, 1966, on file with the California Law Review. Mr. Wright's committee is responsible for a "hard and critical scrutiny" of the Canons of Professional Ethics, which he concedes are "for the most part relevant to an earlier era." This scrutiny will form the basis of the recommendations it presents to the Association's House of Delegates for the new Code. Wright, The Canons of Professional Ethics, Conference Procendngs, National Conf. on Law and Poverty 141, 142-43 (Washington D.C., June 23-25, 1965).

13 Wright, The Canons of Professional Ethics, supra note 12, at 143.

14 H. DRENkER, supra note 6 , at 309 n.1.

15 See Ratner, supra note 9, at 413.

10 Fail v. Gulf States Steel Co., 205 Ala. 148, 87 So. 612 (1920); Hildebrand v. State Bar, 18 Cal. 2d 816, 823-24, 117 P.2d 860, 863-64 (1941) (applying Rules of Professional Conduct of the State Bar of California) ; People ex rel. Chicago Bar Ass'n v. McCallum, 341 III. 578, 589-92, 173 N.E. 827, 831-32 (1930); In re Sizer, 306 Mo. 356, 375, 267 S.W. 922, 928 (1924); cf. Mytton v. Missouri Pac. R.R., 211 S.W. 111 (Mo. App. 1919). But see Johnson v. Great N. Ry., 128 Minn. 365, 369-70, 151 N.W. 125, 127 (1915) (court declined to consider whether nse of loans as inducements for employment was "ethical" but found no objections on "public policy" grounds).

17 People ex rel. Chicago Bar Ass'n v. McCallum, 341 III. 578, 589-90, 173 N.E. $82 \overline{7}, 831$ (1930) (by implication, citing Potter v. Ajax Mining Co., 22 Utah 273, 61 Pac. 999 (1900) and Canon 42, both requiring chent to be ultimately liable for litigation expenses); Johnson v. Great N. Ry., 128 Minn. 365, 369-70, 151 N.W. 125, 127 (1915) ; “cf. Mytton v. Missouri Pac. R.R., 211 S.W. 111 (Mo. App. 1919); State ex rel. Nebraska Bar Ass'n v. Rein, 141 
recognizing that with them clients might withstand unjust settlement offers they would otherwise accept out of necessity. ${ }^{18}$

The Canons of Professional Ethics do not deal specifically with loans for living expenses, and the courts did not cite them in developing their rule, not even in disciplinary proceedings. ${ }^{10}$ Although several of the canons may have infiuenced the restrictions which the courts incorporated into their standard of permissible loanmaking, ${ }^{20}$ no canon or combination of canons was considered to prohibit loans for living expenses.

While the courts were validating loans for living expenses, the Legal Ethics Committee of the New York City Bar Association was issuing a series of advisory opinions ${ }^{21}$ condemning such loans as unethical. The Committee viewed loans as improper "financing of litigation"22 by attorneys who would thereby acquire an "undue personal interest" clients' claims. It also found a "real danger that such loans might induce a chent to employ one attorney rather than another."24 The New York City Committee's opinions, applying the Canons of Ethics, presaged

Neb. 758, 4 N.W.2d 829 (1942); Potter v. Ajax Mining Co., supra. (all involving advances of litigation expenses).

In effect, the courts were saying they approved of loans but not of conditional advances. A loan is an advance of money to one who promises absolutely to repay it. Bankers Mortgage Co. v. Commissioner, 142 F.2d 130, 131 (5th Cir. 1944). However, not all advances are loans; some advances consist of money furnished on credit which is to be repaid conditionally. See Powder Co. v. Burkhardt, 97 U.S. 110 (1877).

Throughout this Comment, the term "advance" is used to denote both unconditional advances (loans) and advances with repayment made contingent upon recovery.

18 People ex rel. Chicago Bar Ass'n v. McCallum, 341 Ill. 578, 589-90, 173 N.E. 827, 831 (1930); Johnson v. Great N. Ry., 128 Minn. 365, 369-70, 151 N.W. 125, 127 (1915).

10 People ex rel. Chicago Bar Ass'n v. McCallum, 341 IIl. 578, 173 N.E. 827 (1930); In re Sizer, 306 Mo. 356, 267 S.W. 922 (1924).

20 The requirement that the chent be obligated to repay the loan whatever the outcome of the litigation is attributable to laws prohibiting champerty. See notes $62,125-32$ infra and accompanying text. Canon 10, which provides that an attorney "should not purchase any interest in the subject matter of the litigation which he is conducting," is construed as prohibiting attorneys from entering into champertous agreements. See notes 96-98 infra and accompanying text.

The condemnation of the use of offers to loan money as a means of securing clients was undoubtedly influenced by Canon 28, which, provides, in part: "It is disreputable to . . . [seek] out those with claims for personal injuries ... in order to secure them as clients ...." ABA Canons of Professtonal Etrucs No. 28. See notes 82-86 infra and accompanying text.

21 New York City Opinions 20 (1925), 319 (1934), 391 (1936), 779 \& 781 (1953), collected in The Ass's of tHe BAR OF THE CITY OF NEW York AND THE NEW YORK County Lawyers' Ass'n, Opintons of the Conantrtees on Professional Etmics 10-11, 168-69, 208, 474-76 (1956) [hereinafter cited as New York City Opinions].

22 New York City Opinion 779, supra note 21, at 474.

23 New York City Opinion 20, supre note 21, at 11.

24 New York City Opinion 779, supra note 21, at 474. 
Opinion 288 of the Legal Ethics Committee of the American Bar Association, ${ }^{25}$ which similarly condemned loans for hiving expenses. Opinion 288, published in 1955, lias had a marked but perplexing impact upon the courts' treatment of such loans.

\section{B. Opinion 288}

The inquiry prompting Opinion 288 involved attorneys who made a practice of advancing "substantial sums of money ... on a regular monthly basis," often in excess of subsistence needs, to their numerous personal injury clients. ${ }^{26}$ The Committee's response, however, was not linited to the specific facts of the inquiry. The Committee summarized its opinion as follows: "Payments, pending trial in personal injury cases, by an attorney to or for the benefit of his injured client, for any purpose other than to cover expenses of hitigation, subject to reimburseinent, are inproper." 27

The Committee first found that Canon 42 "furnishes no justification for [advances for living expenses]." ${ }^{28}$ Canon 42 , added to the original Canons in $1928,{ }^{29}$ permits an attorney to advance hitigation expenses subect to reimbursement by the client. ${ }^{30}$ Although it condones a widespread practice ${ }^{31}$ by endorsing the prior judicial rule, ${ }^{32}$ Canon 42 is enigmatically silent on loans for living expenses, ${ }^{33}$ which liad been governed by the same

25 OpINION 288, supra note 8.

$26 I d$.

27 Id.

$28 I d$.

29 H. DrINKER, supra note 6 , at 309 n.1.

30 "A lawyer may not properly agree with a client that the lawyer shall pay or bear the expenses of litigation; he may in good faith advance expenses as a matter of convenience, but subject to reimbursement." ABA Canons of Professionat EtHrics No. 42.

31 "Most standard fee contracts call for the lawyer to advance . . . costs for his client subject to reimbursement whatever the outcone of the claim." F. MAcKINNON, supra note 1, at 69. MacKinnon adds that "As a practical matter, the lawyer typically does not press for this reimbursenent if no recovery is obtained. Therefore, in fact, in many areas of the country, lawyers . . . bear the full financial burden of instigating and prosecuting the claim, particularly in personal injury practice." $I d$.

32 Potter v. Ajax Mining Co., 22 Utah 273, 290-91, 61 P. 999, 1003 (1900).

33 The only court to consider the relation of Canon 42 to loans for living expenses prior to Opinion 288 suggested that the case in favor of such loans was strengthened by the new Canon, since they are analogous to the advances of hitigation expenses which that Canon permits. People ex rel. Chicago Bar Ass'n v. McCallum, 341 Tll. 578, 589-90, 173 N.E. 827, 831 (1930); see In re Ruffalo, 249 F. Supp. 432, 442 (N.D. Ohio 1965) (commenting on McCallum's treatment of Canon 42). The court did not, as Opinion 288 contends, hold that loans for living expenses were "contemplated by and justifiable under Canon 42." OPINION 288, supre note 8. "In McCallum, the Illinois Supreme Court does not say that the advances there involved [loans for living expenses] were specifically justifiable under Canon 42." In re Ruffalo, supra at 442. 
judicial rule. ${ }^{84}$ The Legal Ethics Committee might have interpreted Canon 42 as implicitly proscribing such loans. Instead, it found that the Canon, while not prohibiting them, provided "no justification" for them, ${ }^{35}$ a view adopted by the courts. ${ }^{36}$

The Committee then asserted, however, that an attorney who loans money to a destitute personal injury client violates Canons 6 and 10, and, if this practice is publicized, Canon $27 .^{37}$ These Canons respectively prohibit an attorney from representing conflicting interests, ${ }^{88}$ purchasing an interest in the subject matter of hitigation he is conducting, ${ }^{80}$ and soliciting professional employment by advertising. ${ }^{40}$

\section{Decisions after Opinion 288}

Two courts have rejected Opinion $288,{ }^{41}$ and two others have ignored it $^{42} \mathrm{~m}$ disciplinary proceedings in which the Canons were applied. These courts followed the prior judge-made rule. However, two other courts have adopted the Legal Ethics Committee's position, in one case dis-

34 Cases cited in note 17 supra.

35 See text accompanying note 28 supra.

${ }^{36}$ E.g., In re Ruffalo, 249 F. Supp. 432, 442 (N.D. Ohio 1965): "It seems clear that Canon $42 \ldots$ is concerned solely with the specific matter of expenses such as court costs, etc., and not with 'living expenses' of the chent. . . . [However], Canon 42 neither implicitly or explicitly provides that advances which are subject to reimbursement, but which are made for other purposes [than to cover litigation expenses], are otherwise improper."

37 OpInION 288, supra note 8.

88 "It is unprofessional to represent conflicting interests, except by express consent of all concerned given after a full disclosure of the facts." ABA CANors of Profrssionar Ethics No. 6. See discussion of this Canon and its effects on loans for living expenses in text accompanying notes 150-63 infra.

89 "The lawyer should not purchase any interest in the subject matter of the litigation which he is conducting." ABA Canons of Professionar Ethics No. 10. For a discussion of purchasing an interest in litigation, see text accompanying notes 92-149 infra.

40 "It is unprofessional to solicit professional employinent by circulars, advertisements, through touters or by personal commumications or interviews not warranted by personal relations." ABA Canons of Professionar ExHICs No. 27. For a discussion of advertising and solicitation see text accompanying notes 164-72 infra.

41 In re Ruffalo, 249 F. Supp. 432, 440-43, 445 (N.D. Ohio 1965); In re Ratner, 194 Kan. 362, 375, 399, P.2d 865, 875 (1965) (as indicated in text accompanying notes 60-63 infra, the court purported to follow Opinion 288 but construed it in a manner which constituted a virtual rejection of it). See also State ex rel. Florida Bar v. Dawson, 111 So.2d 427,430 (Fla. 1959), in which the court disapproved of the use of loans for personal expenses as inducements for employinent, but stated that once a lawyer is employed he may, the court felt, advance sums "incidental to the conduct of the client's business." It is not clear whether such advances could include loans for living expenses. See Comment, Advancements to Client by Attorney, 17 AIA. L. REv. 313, 314 (1965).

42 In re Moore, 8 Ml. 2d 373, 134 N.E.2d 324 (1956), 6 DE PAUL L. REv. 148, 151 (1956); State $e x$ rel. Beck v. Lush, 170 Neb. 376, 103 N.W.2d 136 (1960). 
barring an attorney for making loans ${ }^{43}$ and in the other refusing to enforce an attorney's clain against his client for repayment of a loan. ${ }^{44}$

\section{The Ruffalo Cases}

The juxtaposition of cases permitting loans for living expenses with cases condemning them has produced bewildering uncertainty for the attorney who contemplates loaning money to clients. This situation is exemplified by the recent case of an Ohio attorney who, after making loans for living expenses, was disbarred from state court practice by the state supreme court ${ }^{45}$ only to have his conduct approved by a federal district court in the same state inquiring into his continued fitness to practice before it. ${ }^{46}$

John Ruffalo, Jr., loaned money for living expenses to two women, widowed by the deaths of their husbands in railroad accidents, while

43 Mahoning County Bar Ass'n v. Ruffalo, 176 Ohio St. 263, 199 N.E.2d 396, cert. denied, 379 U.S. 931 (1964). Ruffalo was suspended indefinitely from the practice of law before Ohio state courts on three grounds: (1) loaning money for living expenses to two clients; (2) hiring a railroad brakeman to investigate cases, some of wlich involved claims against the investigator's employer; and (3) exhibiting a contemptuous attitude toward a court which disciplined him for prior misconduct. Id. at 270, 199 N.E.2d at 401.

44 "This court will not lend its office to, or in any way encourage or sanction, the practice of attorneys advancing or loaning funds to clients for living expenses ...." El Janny v. Cleveland Tankers, Inc., 209 F. Supp. 91, 94 (N.D. Ind. 1962).

45 Case cited in note 43 supra.

48 In re Ruffalo, 249 F. Supp. 432 (ND. Ohio 1965). Pursuant to U.S. Dist. Ct., ND. Ohio, R. I(E), Ruffalo was required to show cause why he should not be disbarred froin practice before the federal district court for the northern district of Ohio in view of his suspension from practice before state courts in Ohio. In re Ruffalo, supra at 433. A state court judgment of disbannent should be followed in a subsequent federal disbannent proceeding unless, from a consideration of the record, it appears to the federal court that (1) there has been a denial of due process, or (2) there is inadequate proof of the facts alleged to establish the misconduct, or (3) there is some other "grave reason" why following the state judgment would conflict with the federal court's duty not to disbar an attorney unless compelled to do so under "principles of right and justice." Selling v. Radford, 243 U.S. 46,51 (1917). Since no question of due process was raised and since the facts supporting the clrarges against Ruffalo were undisputed, the federal district court's finding that Ruffalo should not be disbarred inust have rested upon (3) above. See In re Ruffalo, supra at 450.

Subsequent to the proceedings before the federal district court, Ruffalo was disbarred from practice before the Court of Appeals for the Sixth Circuit; In re Ruffalo, 370 F.2d 447 (6th Cir. 1966), prob. juris. noted, 36 U.S.L.W. 3126 (U.S. Oct. 10, 1967) (No. 73). The circuit court's decision sidestepped the issue of the propriety of Ruffalo's loans and rested entirely upon his hiring of a railroad employee to investigate claims against the railroad. Since the federal district court's decision was not on appeal in the circuit court, where an independent disbarment proceeding was held, the lower court apparently was not required to enter its final order in accordance with the views of the circuit court. Compare In re Ruffalo, 370 F.2d 447 (6th Cir. 1966), with In re Ruffalo, 249 F. Supp. 432, 450 (N.D. Ohio 1965). However, should the Supreme Court uphold the circuit court's decision, the district court would very likely enter its final order in accordance with the Supreme Court's opinion. 
representing them in actions under the Federal Employers' Liability Act. ${ }^{47} \mathrm{He}$ made the loans at their request after they had retained him. Although both clients repaid the loans out of the proceeds from settlement of their claims, Ruffalo and they had agreed that the obligation to repay was not contingent on the outcome of the litigation. ${ }^{48}$

Although these loans were unquestionably proper under the "settled course of decisions"49 prior to Opinion 288 the Ohio Supreme Court held in Mahoning County Bar Association v. Ruffalo ${ }^{50}$ that Ruffalo violated Canon 10 which states that an attorney should not "purchase an interest in the subject matter of hitigation which he is conducting." The court reasoned:

It is obvious that, where the advancement of living expenses is made ... to enable a disabled chient and his family to survive, any agreement by the disabled chent to repay ... would not ... [provide] the attorney with any reasonable source of repayment other than the proceeds received on trial or settlement of his client's claim. In effect, the attorney has purchased an interest in the subject matter of the litigation. ... ${ }^{51}$

This interpretation of Canon 10 is identical with that given by the Legal Ethics Counmittee in Opinion $288^{.2}$ Under this view of Canon 10, it is the client's very indigence whicl makes the loan unethical. His lack of assets other than his claim for damages and his probable inability to earn income in the near future because of injury ${ }^{63}$ render the client ineligible for financial assistance under the "purchase-of-an-interest" test employed by the Ohio Supreme Court and by the Legal Ethics Committee.

4745 U.S.C. $\$ \$ 51-60$ (1964).

48 In re Ruffalo, 249 F. Supp. 432, 440, 443 (N.D. Ohio 1965). The federal district court's statement of the facts is based upon the same record which the Board of Commissioners on Grievances and Discipline originally submitted to the Ohio Supreme Court. Id. at 438-39; Mahoning County Bar Ass'n v. Ruffalo, 176 Ohio St. 263, 199 N.E.2d 396 (1964).

49 Ratner, supra note 9, at 413.

50176 Ohio St. 263, 199 N.E.2d 396, cert. denied, 379 U.S. 931 (1964).

51 Id. at 264-65, 199 N.E.2d at 398.

52 "For a lawyer to advance . . . living costs is similar to making an advance on account of the prospective verdict. Clearly there is no expectation of reimbursement except out of the verdict. Accordingly, a lawyer who makes such advances acquires thereby an interest in the subject matter of the litigation which he is conducting, in violation of Canon 10." Opinron 288, supra note 8. See Dombey, Tyler, Richards \& Grieser v. Detroit, T. \& I.R.R., 351 F.2d 121, 129 (6th Cir. 1965); In re Ruffalo, 249 F. Supp. 432, 441 n.6 (N.D. Ohio 1965).

53 Although Ruffalo's loans were made to two women who had been widowed by the deaths of their husbands, see text accompanying note 47 supra, the Obio Supreme Court found that lie lad violated the Canons of Ethics by loaning money to "disabled" clients. See text accompanying note 51 supra. Despite the court's apparent mistake in this regard, its reasoning seems applicable to widows or other survivors of accident victims. For example, a woman suddenly deprived of her busband's support may be just as likely as an injured person not to earn income for some time after the accident, particularly if the woman has never worked before, is unskilled, has young children, or is advanced in age. 
The federal district court in In re $R u f f a l o^{54}$ could not accept such a result:

It is not in consonance with this Court's concept of justice or the underlying purposes of the Canons of Professional Ethics that a loan otherwise proper is rendered improper because of the indigency of the client. ... .55

Whether it be the attorney's fee, the expenses of litigation, or unconditional loans, the fact that it might be difficult or unlikely that the client will be able to reimburse the attorney . . . absent a recovery on his claim slould not render the attorney's conduct improper. ${ }^{56}$

To the In re Ruffalo court, a loan does not constitute purchasing an interest in litigation so long as the obligation to repay is unconditional, however unlikely it is that the client will be able to repay the loan without substantial recovery from trial or settlement. ${ }^{67}$ This view accords with the established judge-made rule. In the pre-1955 decisions, the requirement of an unconditional obligation to repay was thought sufficient to avoid laws against champerty. ${ }^{68}$ Using the champerty rationale, the courts never demanded a showing that repayment was likely whatever the outcome of the litigation. ${ }^{59}$

\section{The Ratner Case}

In re Ratner, ${ }^{60}$ decided the same year as In re $R$ uffalo, reached the same conclusion as Ruffalo regarding Canon 10's applicability to loans. In Ratner, the Kansas Supreme Court found that there is no purchase of an interest in hitigation so long as the obhgation to repay is unconditional. ${ }^{61}$ However, the court held, in the face of explicit language to the

54249 F. Supp. 432 (N.D. Ohio 1965).

$55 I d$. at 443 .

58 Id. at 445 .

$57 I d$. at 443 .

58 See note 125 infra and text accompanying notes $125-29$ infra. Champerty is an agreement in which one who is not directly interested in a claim, the champertor, agrees to assist the owner of the claim in hitigating it in return for a share of the recovery. Sedgwick v. Stanton, 14 N.Y. 289, 294 (1856); F. MACKinnon, ContINGent Fees gor LEgal Services 35-36 (1964). It is usually considered essential to a champertous agreement that the champertor agree to carry on the litigation at his own expense. Omaha \&. R.V.R.R. v. Brady, 39 Neb. 27, 57 N.W. 767 (1894); Reece v. Kyle, 49 Ohio St. 475, 481, 31 N.E. 747, 748 (1892). The share of the recovery is usually provided by a contingent fee when an attorney is the champertor. See note 107 infra.

59 See text accompanying notes 131-33 infra.

60194 Kan. 362, 399 P.2d 865 (1965). Payne H. Ratner, Sr., the attorney exonerated in this case from charges of improper lending to clients, is a former Governor of Kansas and the author of the article cited note 9 supra criticizing Opinion 288.

61 Id. at 375,399 P.2d at 875. In this case, the attorney did not Iend the money himself; he helped a number of his clients to obtain loans from a bank of which he was a 
contrary in Opinion $288,{ }^{62}$ that the Opinion actually permitted this result. $^{68}$

The Ratner decision illustrates that a court may follow the established rule regarding loans for living expenses without openly disagreeing with the prestigious Legal Ethics Committee simply by construing Opinion 288 as a restatement rather than a rejection of the judge-made standard. However, this approach has limited utility in evading the Committee's strict views. No plausible construction of Opinion 288, for example, could attenuate its plain statement that the practice of loaning money for living expenses produces a conflict of interest between attorney and client in violation of Canon $6 .^{64}$ Opinion 288's discussion of conflicting interests was not put at issue in Ratner, In re Ruffalo, or Mahoning County Bar Association v. Ruffalo and has not been considered in any other case to date. $^{65}$

Both Ratner and In re Ruffalo discussed a third issue raised in Opinion 288 , namely that the practice of making loans may lead to improper solicitation of clients in violation of Canon 27.86 The Opinion states that the practice of making loans, "if publicized, constitutes a holding out by

director, and he acted as cosignor on the promissory notes executed by the clients. The court chose not to rely entirely on this factor in finding that he bad not violated Canon 10 as construed in Opinion 288. This seems proper since there is no difference in substance between an attorney's lending money to a client himself and acting as guarantor for a loan to the client from a third party. For the view that an attorney's cosigning a chient's promissory note is just as improper as his lending the money himself, see New York City Opinion 781, sulpra note 21 , at $475-76$.

62 Authorities cited in note 52 supra and text accompanying note 27 sutpra.

63194 Kan. at 375, 399 P.2d at 875. MacKinnon also appears to misinterpret Opinion 288 , citing it for the proposition that "loans to the chent with repayment subject to successful outcome of the claim are held to be professionally improper . . . " F. MacKivnon, supra note 58, at 68 \& n.23 (n.23 erroneously reads "Opinion No. 283" instead of "Opinion No. $\left.288^{\prime \prime}\right)$.

64 OpInion 288, supra note 8. For discussion of the conflict of interest issue, see text accompanying notes 150-63 infra.

${ }^{65}$ In Dombey, Tyler, Richards \& Grieser v. Detroit, T. \& I.R.R., 351 F.2d 121, 130 (6th Cir. 1965), the court stated: "[T] chent's cause of action is primarily that of creating a danger of divergence between the attorney's and the client's interests." (dictum, pointing out "relevant lines of inquiry" in remanding to lower court). In Grievance Comm. of Fairfield County Bar v. Nevas, 139 Conn. 660,96 A.2d 802 (1953), an attorney loaned money to a businesswoman client for a business venture of hers. In finding that the lower court bad not abused its discretion by refusing to disbar the attorney, the Supreme Court of Errors of Connecticut held: "By loaning money to his client, the defendant put himself in a position where his personal interests might well become adverse to hers. The making of such a loan by a lawyer is not, bowever, necessarily unethical conduct. It is unethical only if the loan is made to accomplish some purpose contrary to the chent's welfare or if, in seeking repayment, the lawyer pursues practices which are unfair or unduly oppressive." Id. at 666-67, 96 A.2d at 805 .

${ }^{68}$ See text accompanying notes 37-38 supra. 
the lawyer of an improper inducement to clients to employ him . . . ."17 This statement appears to reaffirm the concern expressed in an opinion of the New York City Bar Association's Legal Ethics Committee that an attorney who makes a regular practice of loaning money nuay improperly influence a prospective client's choice of attorney. ${ }^{68}$

In In re Ruffalo, the court concluded that since the attorney was not engaged in a "wide scale practice of making substantial loans to a large number of his clients" it would be "unreasonable" to find that his lending was "calculated to solicit employment . . . or . . . a gimmick to unethically advertise his services." $"$ In Ratner, the court recognized that frequency of lending could be equated with improper solicitation, but held that proof of loans to sixty-seven out of three hundred twelve railroad accident claimants created too "tenuous" an inference that the attorney was advertising loans to warrant disciplinary action. ${ }^{70}$

Neither the In re Ruffalo or Ratner court delineated the precise connection between a frequent or regular practice of loaning inoney and improper solicitation of business. Frequent loans by an attorney might constitute circumstantial evidence that he was actually advertising his willingness to lend nioney to clients. On the other hand, the practice of making frequent loans might itself give the attorney a reputation for money lending whicli would attract clients. Advertising loans would clearly violate Canon $27 .{ }^{71}$ In Opinion 288, the Legal Ethics Committee apparently felt that acquiring a reputation for loan making also would violate Canon 27.

\section{Present Uncertainty}

As matters now stand, in the aftermath of Opinion 288, an attorney anxious to abide by the profession's ethical standards faces a dilemma if he wishes to lend money to a client for living expenses. If he refuses to make a loan, he may later discover that the courts in lis state would approve sucli loans. In the meantime, his client may suffer and perhaps even retain another attorney. ${ }^{72}$ On the other hand, if he makes a loan, he is forced to run a grave risk of disciplinary action. He has no assurance that his client's unconditional promise to repay a loan will preclude a finding that he has violated Canon 10 by purchasing an interest in litigation.

\footnotetext{
67 OpINION 288, supra note 8.

68 New York City Opinion 391, supra note 21, at 208.

69249 F. Supp. at 443.

70194 Kan. at 374-75, 399 P.2d at 874-75.

71 See note 40 supra. See generally H. DrInkER, LEGAL ETHros 218-19 (1953).

72 See El Janny v. Cleveland Tankers, Inc., 209 F. Supp. 91, 92 (N.D. Ind. 1962) (client discliarged attorneys "because they wouldn't loan me money").
} 
Although the attorney scrupulously avoids sohciting potential chents through offers of loans, he risks being disciplined for violating Canon 27 by simply loaning money too often. Even if he loans money to but one client whose promise to repay is found to avoid "purchase-of-an-interest" objections, the attorney may be held to have violated Canon 6 by representing conflicting interests.

Because appellate courts in many jurisdictions have never considered the propriety of loans for living expenses, attorneys are forced to guess which line of precedent these courts will follow. Even in jurisdictions where a pre-1955 decision has upheld such loans, attorneys have no guarantee that the courts will not reverse themselves on the basis of Opinion 288.

The writer submits that the existing uncertainty is intolerable. If loans for hiving expenses are pernicious under all circumstances, the profession's ethical guidelines should say so clearly. If they are proper under certain conditions, these guidelines should delineate the permissible bounds of lending activity. Any clear rule would be better than none. However, formulation of a rational and fair rule must proceed from a coherent examination of the relevant issues. Both the courts and the Legal Ethics Committee have offered assertions and conclusions rather than analysis. The analysis proffered by this Comment focuses on the rationale bchind loans for living expenses and on the ethical problems which arise in connection with them.

II

FACTORS INFLUENCING CHOICE OF A RULE

\section{A. Purpose of the Loan}

\section{Proper Purpose: Aid to the Client}

An ahien seaman retained an attorney to bring an action for damages for personal injury against his einployer, a steamship company. The attorney's investigation convinced him that the company's negligence had caused the injury and that the seaman had a meritorious claim. Because the client's injury had not yet healed and he was unable to work, the attorney considered several possible means of giving him needed financial help. In an inquiry directed to the Legal Ethics Committee of the New York City Bar Association the attorney asked: "[W]ould it be improper for me as his attorney to advance him a little money to keep him from actual physical suffering pending his trial?" The attorney explained: " $[\mathrm{I}] \mathrm{f}$ he is permitted to starve, his physical suffering will be such that he will be compelled to accept a small and inadequate settlement offer that [the defendant] has made. I consider that the amount they have 
offered him is about one-twentieth of what a jury would award my chient.".73

Although the New York City Legal Ethics Committee replied that such an advancee would give the attorney an "undue personal interest" in the case, ${ }^{74}$ most courts have felt that enabling a chent to resist inadequate settlement offers and to litigate his claim or settle it on reasonable terms amply justifies an attorney's lending money to a chent for living expenses. ${ }^{75}$ In view of the injured plaintiff's frequent inability to obtam a speedy trial ${ }^{76}$ - because of a backlog of cases in the courts, ${ }^{77}$ the general slowness of judicial procedure in civil actions, ${ }^{78}$ or the defendant's delaying tactics ${ }^{79}$ - there is a substantial likelihood that a destitute claimant will be compelled to abandon his claim or settle it for a trifling amount unless he can obtain financial assistance. ${ }^{80}$ Courts which have condemned loans for hiving expenses ${ }^{81}$ have not undertaken to refute this fact. Nor have they denied that such clients often find it difficult to secure financial aid from sources other than their attorneys.

In the absence of overriding considerations militating against any lending by attorneys, loans made for the purpose of enabling clients to pursue legitimate claims should be permitted. On the other hand, if the purpose of a loan is not to aid the client but to secure employment for an attorney, the attorney's conduct should rightly be censured.

\section{Improper Purpose: The Use of Loans as Inducements for Employment}

An attorney who seeks out a potential personal injury client and attempts to secure employment thereby is guilty of "ambulance chasing," a practice which is widely condemned ${ }^{82}$ and clearly unethical under

73 New York City Opinion 20, supra note 21 , at 10,11 .

74 Id. at 11 .

76 People ex rel. Chicago Bar Ass'n v. McCallum, 341 Il. 578, 589-90, 173 N.E. 827, 831 (1931); Johnson v. Great N. Ry., 128 Minn. 365, 369-70, 151 N.W. 125, 127 (1915); Mahoning County Bar Ass'n v. Ruffalo, 176 Ohio St. 263, 272-73, 199 N.E.2d 396, 403 (1964) (dissenting opinion); cf. Christie v. Sawyer, 44 N.H. 298 (1862).

70 "In Cook County, IIl, the average litigant seeking a jury trial in a civil damage case lias to wait five years, Sen. Josepl D. Tydings, D-Md. [chairman of the Senate Subcommittee on Improving Federal Judicial Machinery] told the Senate the other day." Bullen, Backlog of Court Cases Alarms U.S., Oakland Tribune, Mar. 14, 1967, at 22, col. 1, 5.

77 H. Zetsex, H. KaIVeN, B. BuchHolz, Detay in the CoUrt (1959).

$78 \mathrm{~J}$. BrenNan, The Cost of the AMIerican Judictal System (1966).

79 See Mahoning County Bar Ass'n v. Ruffalo, 176 Ohio St. 263, 273, 199 N.E.2d 396, 403 (1964) (dissenting opinion).

80 See text accompanying note 73 supra.

81 See cases cited in notes $43-44$ supra.

82 Nichols, What is a Complete Policy for the Bar to Adopt in Personal Injury Cases?, 6 Car. Sx. B.J. 21 (1931). Contra, Brennan, The Bugaboo "Ambulance Chasing," 
Canon $28 .^{83}$ An offer to loan money is a common means of "ambulance chasing." ${ }^{84}$ Courts have consistently condemned this use of loans for living expenses, ${ }^{85}$ and some states have passed statutes forbidding it. ${ }^{80}$

Loans which serve as inducements should probably be proscribed only in cases where the attorney initiates the loanmaking. Some courts have suggested that the promise of a loan should not be allowed to influence a client's decision to employ a particular attorney. ${ }^{87}$ However, no good reason appears for precluding an attorney from agreeing, upon the request of a prospective client ${ }^{88}$ who has come to him, to loan the client money if he employs him. This type of preemployment agreement does not constitute "ambulance chasing" and, in view of the client's right to dismiss an attorney at will, ${ }^{89}$ is no different in substance than an agreement made after the attorney is retained. A client desiring a loan can always employ an attorney, immediately request a loan, and terminate the employment if the attorney refuses.

6 CAL ST. B.J. 37 (1931). A primary vice in ambulance chasing is the unfair advantage taken by attorneys or their agents who use high-powered salesmanship to pressure people still in pain and unable to exercise calm and reasoned judgment into signing retainers. It has been recognized, however, that this phenomenon has been brought about partly by the equally reprehensible practice of some claims adjusters in getting quickly to the injured person in order to obtain a release or a cheap settlement, or to dissuade him from consulting an attorney. Comment, Ambulance Chasing in Illinois, A Success Story, 1957 U. Irr. L.F. 309,311 . See generally Wasservogel, Report in the Matter of the Investigation Ordered by the Appellate Division of the Supreme Court in and for the First Judicial Dep't, by Order Dated February 7, 1928, upon the Petition of the Ass'n of the Bar of the City of New York, New York County Lawyers' Ass'n and the Bronx County Bar Ass'n, for an Inquiry by the Court into Certain Abuses and Illegal and Improper Practices Alleged in the Petition, 14 Mass. L.Q. 1 (November, 1928). See also Yoder, How an Ambulance Chaser Works, SarURDAY Evenna Post, March 23, 1957, at 19.

83 "It is disreputable ... to breed hitigation by seeking out those with claims for personal injuries ... in order to secure them as clients ...." ABA Canons of ProfesSTOAATL ETHICS No. 28.

84 See People ex rel. Chicago Bar Ass'n v. McCallum, 341 ml. 578, 588, 173 N.E. 827, 830 (1930).

85 See cases cited in note 16 supra.

80 E.g., Tex. Pen. Code Ann. art. 430 (1952); Wasr. Rev. Code ANv. § 9.12.010 (1961).

87 In re Sizer, 306 Mo. 356, 375, 267 S.W. 922, 928 (1924) (loan upheld because it was not "consideration" for the employment of the attorney). In In re Ruffalo, 249 F. Supp. 432, 443 (N.D. Ohio 1965), the court appeared to attach importance to the fact that "the loans were made after the clients had retained Respondent to represent them ...."

88 As used in this Comment, the term "prospective chent" refers to a person who comes to an attorney and either seeks to employ him or inquires into the possibility of doing so. The term "potential client" refers to a person who has or may have a cause of action against another for damages and who is sought out by an attorney wishing to secure him as a client.

89 "One of the basic features of the lawyer-client relationship is the fact that it is terminable at will at the option of the client, with or without cause." F. MacKnNoN, supro note 58 , at 77 . 
A loan which materially exceeds the client's requirements for food, shelter, medical attention and other necessities may be presumed to have been offered as an inducement for employment, absent direct proof to the contrary. An attorney who loans money as an inducement has an incentive to lavish funds on a client which an attorney wlio does not loan money for this purpose does not liave. When an attorney seeks out a person he beheves to have a potentially lucrative claim, he may not hesitate to offer to maintain him liberally ${ }^{90}$ during the litigation, hoping that his attractive offer will win him over as a client. Because a substantial recovery is likely, the attorney can expect repayment of the loan as well as a handsome fee.

A prohibition against attorneys lending nnoney in an amount which inaterially exceeds their good faith estimate of a client's subsistence needs would discourage the use of loan offers in sohciting employment but would not frustrate legitimate lending. Such a limitation would be a desirable exception to a broad rule allowing noninducement loans to enable chients to pursue their claims. The exception would invalidate loans wlich are excessive but whicli cannot otherwise be shown to have been offered as inducements.

\section{An Overlap of Purposes}

While it is probably true that some loans are offered as inducements despite the absence of any need on the client's part, inducement loans may also be intended to serve the purpose of enabling a client to persevere in his claim. In these situations, the attorney may have both a proper and an improper purpose for extending a loan. However, a rule prohibiting attorneys from offering loans as inducements, regardless of the collateral functions of such loans, will not prevent deserving clients from obtaining financial assistance, for they can request it themselves. ${ }^{91}$ Therefore, attorneys should not be allowed to offer loans as inducements even when such loans fulfill a dual purpose.

A rule permitting attorneys to loan money for the "proper purpose" of enabling clients to secure just awards for their claims presupposes that

80 People ex rel. Chicago Bar Ass'n v. McCallum, 341 III. 578, 589, 173 N.E. 827, 830 (1930).

91 When, in the course of a discussion resulting in an employment contract, an attorney and a prospective client agree upon a loan from the former to the latter, it may be difficult to determine which one really raised the question of a loan. An attorney who is aware of a prospective client's financial plight may direct the conversation to that subject and perhaps prompt an otherwise reluctant person to request financial assistance. To the extent that an artful attorney can put words in the client's mouth, the distinction between an attorney's offering a loan and acceding to a request for a loan is tenuous. However, the ability of some attorneys to "offer" loans indirectly to certain clients does not seem to the writer sufficient justification for failing to prohibit loans which are directly and overtly offered by an attorney. 
such loans pose no serious ethical problems. Therefore, it must be considered whether permitting such loans raises real dangers of a purchase of an interest in litigation, a conflict of interests, and advertising.

\section{B. Objections to "Proper Purpose" Loans}

\section{The Purchase of an Interest in Litigation}

The controversy engendered by Opinion 288 has so far centered around the deceptively simple command in Canon $10^{02}$ that an attorney "should not purchase any interest in the subject matter of the litigation which he is conducting." The Ohio Supreme Court and the Legal Ethics Committee feel that this Canon prohibits loans for hiving expenses to destitute personal injury chents ${ }^{93}$ while other courts regard it as barring only contingent advances covering such expenses. ${ }^{94}$ This Comment concludes that loans or unconditional advances are permissible under Canon 10 and that any doubt in this matter should be resolved in favor of such loans in the new Code of Professional Responsibility. ${ }^{05}$

"Canon $10 \ldots$ is a vestigial remnant of the medieval law against chaniperty . . . ." It prohibits attorneys from engaging in two types of champertous conduct: purchasing claims for the purpose of speculative litigation $^{97}$ and agreeing to bear the expenses of a client's suit in return

82 The case law does not define the scope of Canon 10. The relatively few advisory opinions of the legal ethics committees of various bar associations applying Canon 10 to a number of specific practices are cited and summarized in H. DRINKER, supra note 71, at 99-101. Probably the most helpful source of information concerning Canon 10 is a group of materials which antedate the adoption of the Canons and constitute, in a loose sense, the "legislative history" of the Canons: (1) G. SHARswood, An Essay on Professionat Etrics 154-55 (5th ed. 1884); (2) Hoffman, Fifty Resolutions in Regard to Professional Deportment, Resolution $X X I V$, printed in H. DrnNkER, supra note 71 , at 338, 343-44; (3) ATABAMA State Bar Ass'n Code of Ethics Rule 38, printed in H. Drinker, supra note 71, at 352, 360 (adopted by the Alabama Bar Association in 1887, this was the nation's first formal code of ethics for attorneys). "The Canons as adopted in 1908 were based primarily on Sharswood's Essay . . . and on [the Alabama Code of Ethics] . . ." American Bar Foundation, Statement of the Special Comm. on Reappraisal of the Canons of Professional and Judicial Ethics (1956), primted in W. TrumbULL, Matertals on the LAwYer's Professionax RESPONSIBIITY 347, 348 (1957). Drinker indicates that Hoffman's Resolution $X X I V$ influenced Canon 10. H. DRINKER, supra note 71, at 99, \& n.38.

03 See text accompanying notes 47-53 supra.

84 See text accompanying notes 54-61 supra.

O5 See notes 12-14 supra and accompanying text.

96 Petitioner's Brief for Certiorari at 16, Ruffalo v. Mahoning County Bar Ass'n, 379 U.S. 931 (1964); see H. DRINKER, supra note 71, at 99.

97 "The purchase of a lawsuit by an attorney ... is champerty in its most odious form." Arden v. Patterson, 5 Johns. Ch. 44, 48 (N.Y. Ch. 1821) (Kent, C.). Although some cominentators regard the prohibition against purchasing of law suits by attorneys as a remnant of the ancient and largely abandoned doctrime of nonassignability of choses in action, see, e.g., F. MAcKnwson, sipra note 58, at 37-38, 40, other commentators, as well as some courts, regard it as a product of the equally ancient but only partially abandoned 
for a share of the recovery..$^{98}$

First, an attorney may not purchase all or part of the subject matter of litigation which he is conducting for a client. ${ }^{90}$ This means that an attorney is forbidden to purchase any interest in the right or claim which his client asserts in such litigation. ${ }^{100}$ Although Canon 10 only refers to purchasing an interest in the subject matter of "the litigation whicl [the attorney] is conducting," it also prohibits an attorney from purchasing claims from nonclients for speculation, that is, in order to litigate such claims for personal profit. ${ }^{101}$

law of champerty. See, e.g., Martin v. Freeman, 216 Cal. App. 2d 639, 642-43, 31 Cal. Rptr. 217, 218-19 (1963) (referring to the California statute quoted in note 101 infra); H. DRnNKER, supra note 71 , at 99 . Probably both views are correct since the doctrine of champerty and the doctrine of nonassignability of choses in action overlap; today, most assignments of choses in action which are invalid are invalid because they are deemed champertous. See, F. Bodemin, Manntenance and Champerty 92-93 (1935); 4 A. Corbin, Contracts $\$ 856$ (1951); Winfield, Assignment of Choses in Action in Relation to Maintenance and Champerty, 35 L.Q. REv. 143, 149 passim (1919).

${ }^{88}$ See note 58 supra and text accompanying notes 125-130 infra.

${ }^{99}$ Canon 10 provides: "The lawyer should not purchase any interest in the subject matter of the hitigation which he is conducting." Hoffman's Resolution XXIV, printed in H. DRINKER, supra note 71, at 344, provides, in part: "[T]he object of my resolution . . . is against purchasing, in whole or in part, my client's rights, after the relation of client and counsel, in respect to it, [has] been . . . established;" see G. SHARswood, supra note 92, at $155 \mathrm{n}$.1. See also Alabadra State Bar Associatron Code of Ethics Rute 38, printed in H. DrnNKER, supra note 71, at 360: "Attorneys ... ought scrupulously to refrain from bargaining about the subject matter of the litigation, so long as the relation of attorney and client continue."

100 The subject matter of a litigation is the right which one party claims against another, such as the right to recover money. Jacobsen v. Miller, 41 Mich. 90, 1 N.W. 1013 (1879); Flower Hosp. v. Hart, 178 Okla. 447, 62 P.2d 1248 (1936). It is the right asserted by the plaintiff. Murray v. Ohio Bell Tel. Co., 67 Obio L. Abs. 417, 429-30, 54 Ohio Op. 82, 88-89, 117 N.E.2d 495, 504 (C.P. 1954).

MacKinnon argues that an attorney employed on a contingent fee basis is a co-owner of his client's elaim. F. Mackivion, supra note 58, at 196. Canon 10 does not, however, prohibit contingent fee contracts. $H$. DrnNKER, supra note 71 , at 99,176 . Most courts hold that a contingent fee attorney does not have an interest in his client's claim, F. MAcKnoron, supra note 58, at 196, but only an interest in the proceeds of the litigation. E.g., Isrin v. Superior Court, 63 Cal. 2d 153, 158-61, 403 P.2d 728, 731-33, 45 Cal. Rptr. 320, 323-25 (1965). This position reconciles Canon 10 with Canon 13, which expressiy sanctions contingent fee contracts.

101 "A lawyer may not properly buy judgment notes or other choses in action for less than their face value, with the intent of collecting them at a profit to himself ...." H. DRINKER, supra note 71, at $100 \mathrm{n.47}$ and accompanying text.

Sharswood's only textual reference to the purchase of the subject matter of litigation by an attorney is in the form of a quotation from a leading New York case, Arden v. Patterson, 5 Johns. Ch. 44 (N.Y. Ch. 1821). G. SEARSwood, supra note 92, at 154-55. In this case, an attorney bought a claim from a nonclient for $\$ 351.31$ and then litigated the elaim, securing a verdict of $\$ 5,987.25$. "The purchase was avowedly made as a matter of speculation, and at a time when this attorney knew, from previous disclosures made to him in his cluaracter of attorney, all the facts ... of the claim ...."Id. at 48. (The attorney had been told of the claim by a client who had assigned it to the individuals from whom the 
The primary reason ${ }^{102}$ for prohibiting attorneys, with their superior ability to evaluate claims, ${ }^{103}$ from purchasing such claims is to prevent them from taking advantage of sellers. ${ }^{104} \mathrm{~A}$ person who is ignorant of the worth of his claim, especially if he is also financially desperate, might well submit to an unjust bargain with an attorney seeking to buy the claim for speculative purposes. ${ }^{105}$

Second, an attorney ${ }^{106}$ may not promise to assume a client's litigation expenses in return for a share of the recovery, ${ }^{107}$ whether his promise is

attorney purchased it.) The court set aside the assignment to the attorney and enjoined him from enforcing the judgment he had obtained; it held that the assignors could enforce it instead. Id. at 53 .

A number of state statutes prohibit attorneys from acquiring claims for the purpose of litigating them. E.g., Cax. Bus. \& Prof. CODE $\S 6129$ (West 1962) ("Every attorney ... who ... buys ... any evidence of debt or thing in action, with intent to bring suit thereon, is guilty of a misdemeanor."); N.X. JuDictaRY LAw \& 488 (McKinney 1966) ("An attorney ... shall not ... buy [or] take an assignment of ... [a] thing in action, with the intent and for the purpose of bringing an action thereon.")

102 At least one court has suggested another reason. "The purpose of [the California statute quoted in note 101 supra] ... is to prevent the officious fomenting of higation. The outright purchasing by attorneys of claims which perhaps otherwise would never be sued upon obviously would tend to stir up a good deal of litigation . . . " Martin v. Freeman, 216 Cal. App.2d 639, 643, 31 Cal. Rptr. 217, 219 (1963).

In addition, some nembers of the profession apparently feel that it is simply undignified or unbecoming for an attorney to use his professional skill and knowledge acquired in a professional capacity to litigate speculatively on his own behalf. See Arden v. Patterson, 5 Johns. Ch. 44, 48 (N.Y. Ch. 1821).

103 Because of their professional training and experience, attorneys are usually able to evaluate claims more accurately than their owners can. F. MAcKonNoN, supra note 58, at 38. This is particularly true when the owner is a client and the elaim is one with which the attorney has thoroughly acquainted himself. See Hoffman, Resolution $X X I V$, printed in H. DRINKER, supra note 71, at 344.

104 See Arden v. Patterson, 5 Johns. Ch. 44 (N.Y. Ch. 1821).

105 Id.

106 "[C]hamperty ... . [has become] almost specialized as a lawyer's transgression. The champertors are nearly always lawyers." Radin, Maintenance by Champerty, 24 CarIF. L. Rev. 48, 66 (1935). Although attorneys are the most frequent champertors, champerty laws typically prohibit anyone from acting as a champertor. See, e.g., Dex. Code ANN. tit. 11 , § 371 (1953). However, "anyone" generally means only strangers to the hitigant receiving financial assistance. A person may give financial assistance to a litigant in return for a share of the recovery if the parties are relatives or stand in a relation such as master and servant or landlord and tenant. Reece v. Kyle, 49 Ohio St. 475, 482, 31 N.E. 747, 749 (1892).

107 Most champertous contracts involving attorneys are contingent fee contracts. It is the contingent fee which provides the attorney with a share of the recovery, an essential component in a champertous agrecment. However, a contingent fee contract is not, by itself, champertous. It is permissible for an attorney to promise to provide services in return for a share of the recovery. A contingent fee contract is champertous only if the attorney, in addition to promising his services, promises either absolutely or conditionally to bear the expenses of the litigation. See Lawrence v. Commodore Navigation Corp., 108 F.2d 563 (2d Cir. 1940); In re Gilman's Adm'rx, 251 N.Y. 265, 167 N.E. 437 (1929); G. WARveLLE, ESSAYS IN IEGAX ETHICS \& 145 (2d ed. 1920). All states now permit contingent fee contracts, subject to various statutory restrictions. See authorities cited in note 2 supra. 
absolute ${ }^{108}$ or contingent upon the outcome of the litigation. ${ }^{109}$ The purported reason for prohibiting ${ }^{110}$ such agreements is to prevent the prosecution of groundless or questionable claims which probably would never come to court if champertous financial assistance were not given to the claimants. ${ }^{111}$

Since these two types of champerty-purchasing of claims and assuming clients' litigation expenses for a share of the recovery-are definitionally distinct and proscribed for different reasons, they will be considered separately in analyzing Canon 10's applicability to loans for hiving expenses. Generally, as in the following discussion, only the latter form of champerty is referred to as "champerty." 112

(a) Purchasing the Subject Matter of Litigation.-In loaning money to a client for living expenses, an attorney neither violates the letter nor frustrates the purpose of Canon 10's prohibition against purchasing an interest in the subject matter of litigation. This becomes apparent from an examination of the nature of the lending attorney's interest in his client's case.

An attorney who loans money to an indigent client often has a "stake in [the client's] . . h htigation." ${ }^{\prime 13}$ This is true because in many cases

Clearly, the exemption of the contingent fee from prohibitions against champerty rests on grounds of policy rather than of logic. See Radin, Contingent Fees in California, 28 CALIF. L. REv. 587, 589 (1940). Contingent fees were formerly considered champertous in the Umited States and still are so considered in England. Id. at 587; Radin, supra note 106, at 70 .

108 Geer v. Frank, 179 Ill. 570, 53 N.E. 965 (1899); Atchison, T. \& S.F.R.R. v. Johnson, 29 Kan. 157 (1883).

${ }^{109}$ Low v. Hutchinson, 37 Me. 196 (1853); State ex rel. Nebraska Bar Ass'n v. Rein, 141 Neb. 758, 4 N.W.2d 829 (1942); cf. Lawrence v. Commodore Navigation Corp., 108 F.2d 563 (2d Cir. 1940).

110 Champerty is prohibited by common law in some states, e.g., Geer v. Frank, 179 III. 570, 53 N.E. 965 (1899); Orr v. Tanner, 12 R.I. 94 (1878), and by statute in some others, e.g., Dex. Code ANn. tit. 11, § 371 (1953); ME. Rev. Stat. ANn. tit. 17, § 801 (1966). In many states, however, there is no law against champerty. See note 142 infra and accompanying text.

111 Huber v. Johnson, 68 Minn. 74, 70 N.W. 806 (1897); Note, 15 CorNele L.Q. 92, 94 (1929) ("The modem law of champerty is designed to prevent the prosecution of questionable claims that otherwise would not arise."); see Radin, supra note 106, at 66-67. Objections to champerty are most often raised by individual and corporate defendants with as interest in keeping imdigent plaintiffs from litigating claims against them. See Reece v. Kyle, 49 Ohio St. 475, 487, 31 N.E. 747, 751 (1892); Radin, supra note 106, at 66.

112 The Restatement of Contracts defines champerty as follows: "Champerty is the division of the proceeds of litigation between the owner of the litigated claim and a party supporting or enforcing the litigation." Restatement of Contracts $§ 540(2)$ (1932). "[A] bargain to endeavor to enforce a claim in consideration of a promise of a share of the proceeds, or any other fee contingent on success, is illegal, if it is also a part of the bargain that (a) the party seeking to enforce the claim shall pay the expenses incident thereto ...." $I d .$, \& $542(1)$.

113 Drinker states that Canon 10 does not preclude an attorney from having a "stake 
repayment is likely or even possible only if the client obtains a substantial recovery or settlement. Sometimes the loan agreement gives the attorney a lien upon any recovery as security for repayment of the loan. ${ }^{114}$ This interest in the proceeds is analogous to the interest which an attorney acquires by law in most states as security for payment of his fee and reimbursement for any advances of litigation expenses. ${ }^{110}$

By loaning money to a client, an attorney does not purchase anything in the usual sense of the word. ${ }^{118}$ Furthermore, Canon 10 does not preclude an attorney from having a "stake" in litigation he is conducting. ${ }^{117}$ Finally, even if the loan agreement gives the attorney a security interest

in his litigation." H. DRENKER, supra note 71, at 99. This undoubtedly means that there is nothing inherently wrong with an attorney's putting himself in a position whereby he stands to gain or lose financially depending upon the outcome of hitigation which he is conducting. A "stake" in litigation is what one court has described as a "pragmatic interest in the client's cause of action" as opposed to an ownership interest therein which Canon 10 proscribes. Dombey, Tyler, Richards \& Grieser v. Detroit, T. \& I.R.R., 351 F.2d 121, 130 (6th Cir. 1965).

114 E.g., People ex. rel. Chicago Bar Ass'n v. McCallum, $341 \mathrm{II} .578,589-90,173$ N.E. 827, 831 (1930). This appears to be the only reported case in which such a lien provision was included in the loan contract.

115 The common law in some states and statutory law in many others give attorneys a "cliarging lien" on the amount recovered by a client. Royal Ins. Co. v. Simon, 20 Del. Ch. 297, 301-02, 174 A. 444, 446 (1934); Stevens, Our Inadequate Attorney's Lien StatulesA Suggestion, 31 WASH. L. REv. 1, 3-7 (1956). This lien "gives a lawyer a protected interest in the proceeds of his client's claim. It allows him to . . obtain his fee and reimbursable expenses out of funds in the hands of the court, defendant, insurance company, or other person, which are due to his client under terms of a judgment or settlement." F. MacKnnoN, Contingent Fees for Legar Services 72 (1964).

116 In Martin v. Freeman, 216 Cal. App. 2d 639, 642, 31 Cal. Rptr. 217, 219 (1963), the court held that CaI. Bus. \& Pror. Code $\$ 6129$ (West 1962), quoted in note 101 supra, applied only to "a purchase in the ordinary sense of the word." An attorney who loaned money to a friend and later accepted an assignment of the friend's claim against the defendant in satisfaction of the debt was found not to have violated the statute.

117 Note 113 supra. MacKinnon states that "[C]ourts consistently hold that too much financial assistance by a lawyer to his client's lawsuit is bad .... [in part because] at some point the lawyer's contingent interest in the outcome becomes dangerous to the court, which depends on his professional independence." F. MAcKnowoss, supra note 115, at 41 (no authorities cited). MacKinnon does not say how much financial assistance is "too much," but it is certainly arguable that loans for living expenses should not be considered "too much." First, the major component of an attorney's financial interest in any case is his contingent fee arrangement. The potential amount of such a fee is almost always much greater than the amount of any advance of litigation expenses or loan of living expenses. Any loss of professional independence due to a financial interest in a case will result from this fee interest and not from any de minimis increment in financial interest attributable to such an advance or loan. Since contingent fees are permissible, see not 107 supra, it would be illogical to invalidate advances or loans. Second, it is not at all clear just what "professional independence" is or whether it is even desirable, particularly if it is to be attained at the expense of clients in need of financial assistance to litigate just claims. The fact that attorneys are not precluded from representing themselves in court illustrates that they are not expected to be neutral or "objective" in litigation. 
in the proceeds, he does not thereby "acquire," much less "purchase," any interest in the subject matter of the litigation.

The difference between an interest in the subject matter of hitigation and an interest in the proceeds of litigation ${ }^{119}$ is significant in terms of the purpose behind the proscription of purchasing claims. A security interest in the proceeds merely enables an attorney to obtain repayment of his loan out of funds, in the hands of either the court or the defendant, which are due to his client under the terms of a judgnient or settlement. ${ }^{120}$ Unlike a case in which the attorney purchases all or part of the claim itself, there is no potential disparity between what the attorney pays or lends and what he subsequently receives. Overreaching and speculation are possible only when such a disparity exists. ${ }^{121}$ Therefore, an attorney with a security interest in the proceeds for repayment of a loan has no opportunity either to deal unfairly with his client or to speculate in litigation.

Insofar as Canon 10 condemns the purchasing of any interest in a claim by an attorney it seems clearly inapplicable to loans for hiving expenses. ${ }^{122}$ However, those who assert that Canon 10 prohibits attorneys from making such loans to destitute personal injury clients ${ }^{123}$ apparently regard these loans as coming within Canon 10's proscription of champerty. ${ }^{124}$

118 "Significantly [Canon 10] uses the word 'purchase,' not 'acquire." H. DRINKER, supra note 71, at 99 .

119 In Isrin v. Superior Court, 63 Cal. 2d 153, 158-61, 403 P.2d 728, 731-33, 45 Cal. Rptr. 320, 323-25 (1965), the California Supreme Court drew a sharp distinction between an interest in the proceeds of litigation and an interest in the subject matter of litigation. The court held that an attorney's interest in litigation he is conducting under a contingent fee contract is an interest in the proceeds.

120 Note 115 supra and accompanying text.

121 See Arden V. Patterson, 5 Johns. Ch. 44 (N.Y. Ch. 1821) (discussed in note 101 supra).

122 Alabaja State Bar Ass's Code of Etritcs Role 38, printed in H. Drinker, supra note 71, states that attorneys ought to "refrain from bargaining [with a client] about the subject matter of the litigation," and also provides: "Attorneys should, as far as possible, avoid becoming either borrowers or creditors of their client ...." This rule does not imply, however, that an attorney who lends money to a chent thereby purchases any interest in the subject matter of the litigation which he is conducting for the client.

Hoffman's Resolution XXIV, printed in H. DRINKER, supra note 71 , at 343 , provides, in part: "Should [my client's] wants be pressing, it will be an act of humanity to relieve them myself, if $I$ am able .... But in no case will $I$ permit ... my benevolence [and my client's] wants ... to seduce me into participation of his pending claim ...." In view of the distinction between a security interest in the proceeds of a claim and an ownership interest in the claim itself, this language does not appear to preclude a loan from attorney to client with repayment secured by a lien on the proceeds. It does preclude financial assistance to a chent given in return for a share of the claim.

123 See text accompanying notes 47-53 supra.

124 See text accompanying note 112 supra. 
(b) Bearing a Client's Litigation Expenses.-The courts have consistently regarded financial assistance to cover a client's living expenses as subject to the restrictions imposed by champerty laws, ${ }^{125}$ apparently on the basis that an indigent chent's living expenses are, in a broad sense, expenses of hitigation. ${ }^{126}$ Accordingly, courts have held that an advance for living expenses, hike an advance of actual litigation expenses, is champertous if the client's obligation to repay is made contingent upon recovery. ${ }^{127} \mathrm{But}$ an advance which the client is unconditionally obligated to repay, that is, a loan, has never been held champertous ${ }^{128}$-at least not until the Ohio Supreme Court's Mahoning County Bar Association v. Ruffalo decision in $1964 .{ }^{128}$

The Ohio Supreme Court and the Legal Ethics Committee both consider any loan for living expenses to an indigent personal injury client unethical under Canon 10. They argue that an attorney who makes such a loan purchases an interest in his client's litigation because, as a practical matter, there is little likelihood of repayment in the absence of a recovery. ${ }^{130}$ They reason, presumably, that such a loan is champertous because it is really no different than an advance made under an agreement providing that the client's obligation to repay is contingent on the litigation's success.

While Canon 10 does proscribe champerty, using it to invalidate bona fide loans is improper on several grounds. First, the probability that a chent will actually repay a loan pursuant to his contractual obligation

125 E.g., Johnson v. Great N. Ry., 128 Minn. 365, 151 N.W. 125 (1915): "[A]n agreement to loan the client funds with which to carry on the suit or to inaintain himself during its pendency is not regarded as per se opposed to public policy. It is only when the attorneys are to ultimately stand the costs, or when the client is indemnified from liability for them in case of no recovery, that the law declares the arrangement void." Id. at 370, 151 N.W. at 127, citing Huber v. Johnson, 68 Minn. 74, 70 N.W. 806 (1897), a champerty case. See also People ex rel. Chicago Bar Ass'n v. McCallum, 341 Il. 578, 589-90, 173 N.E. 827,831 (1930) (by implication), citing Johnson v. Great N. Ry., sutpra, and Potter v. Ajax Mining Co., 22 Utah 273, 61 Pac. 999 (1900), a champerty case.

126 Since payment of such a client's living expenses is often essential to the initiation or continuance of litigation on his behalf, it seeins reasonable to treat these expenses in this manner. See text accoinpanying notes 73-80 supra.

127 E.g., Johnson v. Great N. Ry., 128 Minn. 365, 370, 151 N.W. 125, 127 (1915) (holding that the loan was not champertous since no proof had been introduced to show that it was a contingent advance).

128 See Johnson v. Great N. Ry., 128 Minn. 365, 370, 151 N.W. 125, 127 (1915); 16 VA. L. REV. 715 (1930).

129 Mahoning County Bar Ass'n v. Ruffalo, 176 Ohio St. 263, 199 N.E.2d 396, cert. denied, 379 U.S. 931 (1964). Although the Ohio Supreme Court used Canon 10's "purchase of [an] interest in ... litigation" language, its decision was clearly based on the notion of clramperty. See Dombey, Tyler, Richards \& Grieser v. Detroit, T. \& I. R.R., 351 F.2d 121, 129 (6th Cir. 1965).

130 See text accoinpanying notes $47-53$ supra. 
is legally immaterial in deciding whether his attorney's conduct is champertous. By definition, champerty is an agreement or contract. ${ }^{131}$ Therefore, a person's conduct is not champertous unless he is carrying out the terms of a champertous agreement. ${ }^{132}$ The courts, in determining if laws of champerty have been violated, look only at the obligations of the parties as defined in the agreement between them. ${ }^{133}$ They do not go behind the terms of a contract to see what its practical consequences are likely to be. In dealing with attorney-client loans they do not presume that a client will fulfill his obligation to repay a loan only if his litigation is successful.

It is well known that attorneys who advance litigation expenses subject to reimbursement by the chent whatever the outcome of the litigation ${ }^{134}$ typically do not seek repayment if there is no recovery. ${ }^{135}$ This practice, necessitated to some extent by the inabihty of unsuccessful clients to repay advances, has never been thouglit to make sucli advances champertous. No reason appears for treating loans for living expenses differently.

Second, the factual assumption that nost destitute clients will be unable to repay loans if they do not recover on their claims is dubious. The poverty of many personal injury chents is only temporary. A client who is injured and unable to work may well be able to repay a loan out of his earnings when he returns to work. ${ }^{136} \mathrm{~A}$ client who is without funds at the time he brings his action may be expecting insurance or pension payments in the near future which he could use to meet his obligation. ${ }^{137}$

131 See note 58 supra.

132 See Adams v. Buford, $36 \mathrm{Ky}$. (6 Dana) 406, 414 (1838).

133 See, e.g., Moore v. New York, C. \& St. L. R.R., 245 Ill. App. 8, 17 (1927). "Before a case of champerty will be made out, it must be shown that a lawyer entered into an agreement with his chent to represent him ... and . . . to pay the costs and expenses of the litigation himself. Such is not the case where the lawyer makes advancements of these amounts for his chent's use." (Emphasis added.) In Clancy v. Kelly, 182 Iowa 1207, 1212-13, 166 N.W. 583, 584-85 (1918), the court found that the attorney's promise to bear the litigation expenses if the case were lost was only an "assurance" to the chent and not part of any agreement. It held that his conduct was not champertous, adding, however, that in Iowa a promise to bear litigation expeuses is not always by itself champertous.

134 Such advances are expressly condoned by Canon 42 . See text accompanying notes 29-30 supra.

135 F. MAcKnNoN, supra note 115 , at 69.

136 See New York City Opinion 781, supra note 21, at 475-76.

137 Iromically, this was the situation in Mahoning County Bar Ass'n v. Ruffalo, 176 Ohio St. 263, 199 N.E.2d 396 (1964), although the Ohio Supreme Court paid no attention to it in asserting that Ruffalo had no reasonable source of repayment except the proceeds of his clients' claims. See text accompanying note 51 supra. "The record in the state: proceeding showed that Mrs. Beighley collected insurance more than sufficient to repay the advances made to her (Tr. 206), and that when Mrs. Clark asked for advances she was 
Clearly, there is no uniform relationship between a client's financial status prior to litigation and his ability to repay a loan after having failed to obtain a recovery.

Third, a rule characterizing financial assistance to cover a client's living expenses as champertous on the basis of who is likely to bear the expenses in case there is no recovery obviously would expand the accepted definition of champerty. If anything, ethical rules against champerty should be abandoned altogether, ${ }^{188}$ not enlarged in scope.

The prohibition of champerty is anachronistic and unnecessary. ${ }^{130}$ Furthermore, as many courts have recognized, champerty often promotes justice rather than thwarting it: ${ }^{140}$

A poor man may have the right upon his side, but be without means to enforce [his] rights in the courts, and possibly against some powerful adversary. Surely ... [it is not] the intent of the law to prohibit a friend from assisting him with the necessary money to enforce his rights, dependent for his reimbursement solely upon the contingency of securing a portion of the property which may be obtained by the litigation. .... $14 \mathrm{i}$

waiting for payments under railroad retirement. (Tr. 134-35)." Respondent's Brief on Order to Show Cause at 9, In re Ruffalo, 249 F. Supp. 432 (N.D. Ohio 1965).

188 Professor Radin argued that courts should scrutinize each champertous transaction to see if there were actual abuses. Case by case scrutiny, he stated, would "substitute judgment by reality for judgment by category .... [T] relieved from the most important part of their task which is to take into account the actual conditions within which the parties before them live." Radin, supra note 106, at 72-73, 78 .

189 See Casserleigh v. Wood, 14 Colo. App. 265, 268-71, 59 P. 1024, 1025-26 (1900); Van Gieson v. Magoon, 20 Hawaii 146 (1910); Radin, supra note 106, passim.

The first champerty law was enacted in England in the late thirteenth century in order to combat blatant abuses of the legal process by feudal lords and barons. The most common abuse arose from the transfer of pretended rights in lands to these powerful men. "Rich and powerful barons would buy up claims, and, by means of their exalted and influential positions, overawe the courts, secure unjust and unmerited judgments, and oppress those against whom their anger might be directed." Casserleigh v. Wood, sutpra at 268-69, 59 P. at 1026. "Juries were made up, in large part, of the dependents of such men, and the processes of law were thus converted into engines of oppression." Reece v. Kyle, 49 Ohio St. 475, 481, 31 N.E. 747, 749 (1892). See generally F. MacKinsos, supra note 115, at 36. The feudal nobles either bought the spurious claims outright, "paying" the transferor a share of the land obtained by the litigation, or agreed to support and manage the litigation on behalf of the owners of such claims in return for a share of the land. Laws against champerty were designed to prevent abuse of the legal process by prohibiting such champertous agreements. See F. Mackinnon, id.

The specific abuses against which champerty laws were originally directed have largcly disappeared. More important, numerous laws relating directly to the legal process itself now serve the function of preventing or at least discouraging groundless and vexatious litigation such as champerty laws were designed to prevent. These include statutes of limitations, the statute of frauds, actions for malicious prosecution, and recording acts. See Casserleigli v. Wood, supra at 269-70, 59 P. at 1026.

140 Radin, supra note 106, at 72.

141 Casserleigh v. Wood, 14 Colo. App. 265, 270, 59 P. 1024, 1026 (1900). 
Many states recognize that champerty is not evil per se and have no laws prohibiting it. ${ }^{142}$ In some states, the only "champerty" laws are statutes prohibiting attorneys from purchasing claims for speculative litigation. ${ }^{143}$ Courts in states which do lave general champerty laws often avoid applying them. ${ }^{144}$

Fourth, there is no reason to believe that allowing loans for living expenses would defeat the avowed purpose for prohibiting champertous agreements-i.e., preventing the litigation of groundless claims. ${ }^{145}$ No one has produced evidence that loans to clients are generally or even frequently made to support baseless actions. Indeed, an attorney is much more likely to loan money to a client with a meritorious claim than to a client whose claim is questionable or spurious. ${ }^{146}$

Finally, it is inexcusable to deny financial assistance to all indigent would-be litigants on the grounds that some of their claims are questionable. The interest in keeping baseless claims out of the courts certainly does not justify such patent discrimination against the poor. Nor slould bad faith be imputed to attorneys who provide their clients with financial as well as professional help. It should be sufficient that under such rules as the present Canon $30^{147}$ an attorney is punislable if in fact lie sup-

142 E.g., id. at 268-71, 59 P. 1024, 1026-27 (1900); Van Gieson v. Magoon, 20 Hawaii 146 (1910); Bentinck v. Joseph Franklin \& Galveston. City Co., 38 Tex. 458, 473 (1873).

143 E.g., Car. Bus. \& Prof. Code $\$ 6129$ (West 1962), quoted in note 101 supra, and described as a champerty law in Martin v. Freeman, 216 Cal. App. 2d 639, 31 Cal. Rptr. 217 (1963). California has no common law doctrine of champerty. Estate of Cohen, 66 Cal. App. 2d 450, 152 P.2d 485 (1944).

144 E.g., Granat v. Kruse, 114 III. App. 488, appeal dismissed, 213 IIl. 328, 72 N.E. 744 (1904) (upholding an agreement providing for payment of hitigation expenses out of the attorney's contingent fee share of the judgment, on the grounds that this is simply a way of fixing the attorney's compensation at a percentage of the amount recovered minus costs); Clancy v. Kelly, 182 Iowa 1207, 1212-13, 166 N.W. 583, 584-85 (1918) (refusing to consider an attorney's promise to bear hitigation expenses if the case were lost as per se champertous). In New Hampshire, the courts apply that state's common law rule against champerty only to cases in which the champertor is stirring up strife by promoting vexatious hitigation. Markarian v. Bartis, 89 N.H. 370,199 A. 573 (1938).

145 See note 111 supra.

146 See Van Gieson v. Magoon, 20 Hawaii 146, 149 (1910): "If an attorney undertakes to pay the [hitigation expenses] he is more likely to do so in a meritorious case than in one devoid of merit."

147 "The lawyer must decline to conduct a civil cause . . . when convinced that it is intended merely to harrass or to imjure the opposite party or to work oppression or wrong .... His appearance in court should be deemed an equivalent to an assertion on his honor that in his opinion his client's case is one proper for judicial determination." ABA Canons of Professtonaz Eratcs No. 30.

"Every pleading of a party represented by an attorney shall be signed by ... [an] attorney of record .... The signature of an attorney constitutes a certificate by him ... that to the best of his knowledge, information, and belief there is good ground to support it .... If a pleading ... is signed with intent to defeat the purpose of this rule, it may 
ports spurious hitigation regardless of whether he loans money to his client in the process.

In asserting that an ethical rule against champerty cannot properly be invoked to condemn bona fide loans to clients, this Comment suggests that perhaps the champerty rule should be eliminated from the profession's code of professional conduct. If this recommendation were followed, agreements to advance inoney to chents with repayment contingent upon recovery would also be proper. However, considerations of champerty aside, there are reasons why contingent advances should be prohibited. First, because an attorney who loans money to clients usually does not seek reimbursement if a client is unsuccessful in his litigation, ${ }^{148}$ clients would receive hittle benefit from contracts compelling this result. Such contracts have the one possible advantage of guaranteeing a client that, in case he loses or obtains only a small award, his attorney cannot press him for repayment. However, allowing such contracts probably would not help clients since the rare attorney who demands repayment from an unsuccessful and impoverished chent is not likely to advance money on contingent terms in the first place.

In addition, a contingent advance is much more likely than a loan to have resulted from an improper inducement for employment. The attractiveness of an attorney's offer to advance money to a potential client certainly is enhanced by an assurance that the client has everything to gain and nothing to lose by agreeing to accept it. On the other hand, an attorney who simply agrees to advance money to a client as a loan and does not do so as an inducement has no incentive to offer such attractive terms. Since proof of inducement is probably difficult to obtain in many cases, ${ }^{149}$ a rule prohibiting contingent advances for living expenses would serve to minimize the number of undetected instances of inducement. In view of the mimmal interest in allowing contingent advances, such a rule seems fair and desirable.

In summary, an attorney's loan for hiving expenses to a destitute client does not violate Canon 10's command that an attorney should purchase neither claims nor any interest therein for the purpose of speculative litigation. Insofar as Canon 10 prohibits attorneys from entering into champertous agreements with their clients, it cannot properly be invoked to condemn bona fide loans. It may be invoked, however, to condemn ad-

be stricken as sham and false . . . F For a wilful violation of this rule an attorney may be subjected to appropriate disciplinary action." FED. R. Crv. P. 11.

148 See F. MACKinNon, supra note 115 , at 69 .

149 In most cases only the attorney and the client know what led to their professional relationship. Therefore, it may often be impossible to secure evidence of inducement unless the client can be persuaded to disclose this information. 
vances with repayment contractually contingent upon recovery, for such advances serve no useful purpose and are frequently offered as inducements to potential clients. They should continue to be proscribed even if ethical restrictions on champertous agreements per se are ehminated.

\section{Conflict of Interest between Attorney and Client}

According to the Legal Ethics Committee, when an attorney loans money for hiving expenses to a client there is such a danger that their interests will come into conflict over possible settlement of the client's claim as to constitute a violation of Canon $6{ }^{150}$ This Canon provides, in part: "It is unprofessional to represent conflicting interests, except by express consent of all concerned given after a full disclosure of the facts." An attorney is admonished not to accept employment when his client's interests will conflict with his $0 \mathrm{wn}^{151}$ or with those of a former or present client. ${ }^{152} \mathrm{He}$ must also avoid potential conflicts of interest. ${ }^{153}$

The Committee fears that an attorney who loans money to a client may accept $t^{154}$ a settlement which is adequate to ensure the attorney's recovery of the amount loaned, but which is not in the best interest of the chent. Such a settlement may provide little for the client who perhaps could have obtained a larger settlement or judgment if the attorney had not acted hastily to protect himself.

For several reasons, the danger that an attorney who has loaned money will accept an inadequate settlement offer does not appear to be great. If the loan is made for the very purpose of enabling a client to reject an inadequate settlement offer, ${ }^{155}$ the attorney is presumably convinced from his investigation that the chent's claim can be settled for a much larger amount or litigated for a substantial judgment.. ${ }^{156}$ The attorney, as a reahistic businessman, will not invest heavily in a case which he feels may have to be settled for a small amount.

150 OPINION 288, supra note 8.

151 H. DrINKER, LegaI ExHICS 109-11 (1953). Courts have held that an attorney may not buy an interest which is adverse to or prejudices that of his client. McArthur v. Goodwin, $173 \mathrm{Cal} .499$, 503, 160 P. 679, 681 (1916) (attorney surreptitiously bought the note and mortgage in the process of foreclosure against his client's property); In re People (Bond \& Mortgage Guar. Co.), 303 N.Y. 423, 103 N.E.2d 721 (1952) (attorney purchased mortgage certificates at less than actual value while acting as attorney for trustees of the holders of the certificates).

152 In re Boone, 83 F. 944, 952-53 (C.C.N.D. Cal. 1897); H. DRRNKER, supra note 151, at 111-12.

153 H. DRTNKER, supra note 151, at 104-05.

154 Although the attorney does not, strictly speaking, have the authority to accept a settlement without his chent's consent, he customarily handles the negotiations for settlement and the client often relies on his judgment and advice. F. MacKinNos, supra note 115, at 77.

155 See text accompanying note 73 supra.

156 See text accompanying note 73 supra. 
In addition, the contingent fee contract, which gives the attorney a percentage of the recovery and thus a common interest with his client in a maximum recovery, ${ }^{157}$ is likely to check any temptation on the attorney's part to recommend a settlement which is inadequate for the client. In almost all cases, the potential size of the fee far exceeds the amount of any loan to the client and therefore the fee will have a correspondingly greater impact on the attorney's settlement decisions. A common problem in contingent fee cases is the attorney's effort to prevent his client from accepting a settlement which the attorney feels is too small. $^{158}$

Even if the possibility that an attorney would recommend an inadequate settlement in order to recover his loan were substantial, the client might prefer to have the loan and take that risk rather than face the probability of having to accept an inadequate settlement out of necessity. Canon 6 permits an attorney to represent conflicting interests "with the express consent of all concerned given after a full disclosure of the facts." This provision appears to allow an attorney to make a loan if the client is informed of the possible conflict of interest over settlement when he requests or accepts the loan.

Related to the possible conflict of interest over settlement is the danger that a loan may make a client liesitant to exercise his right to abandon his claim, ${ }^{159}$ discharge his attorney, ${ }^{160}$ or accept a settlement to which the attorney objects. ${ }^{161} \mathrm{~A}$ client who accepts a loan from lis

157 F. MACKnowor, supra note 115, at 196. However, "Where the fee is a flat percentage rate ...., or a declining percentage with an increase in recovery, the question may arise for a lawyer of whether an increment in recovery for the client will require an additional amount of work which is not offset by an increment in the fee. (This question assumes a situation which is ... usual ... in which the chances of some settlement are very high, the likelihood of being forced to go to trial before an offer of settlement is made is very low, and the amount of the settlement is uncertain, being dependent upon the amount of work put into the case by the lawyer.)" Id. at 198.

168 Id. at 74-77.

${ }^{150}$ An attorney's contingent fee contract does not give him a right to continue a suit which the client wishes to drop. Chase v. Superior Court, 210 Cal. App. 2d 872, 27 Cal. Rptr. 383 (1962). In California, "[a]n attorney employed under a contingent fee agreement who is wrongfully discharged by his client, is generally entitled to the same amount of compensation and under the same contingency as if he had completed the services contemplated." Jones v. Martin, 41 Cal. 2d 23, 27, 256 P.2d 905, 907 (1953). The majority rule is that an attorney discharged without cause may recover a "reasonable fee" for services actually performed. Martucci v. Brooklyn Children's Aid Soc'y, 284 N.Y. 408, 31 N.E.2d 506 (1940); Froedtert Grain \& Malting Co. v. Peter P. Woboril, Inc.; 265 Wis. 456, 61 N.W.2d 855 (1953); see F. MACKronos, supra note 115, at 79.

$160 \mathrm{~A}$ client may discharge his attorney at any time with or without cause. Courts will not force continuance of the attorney-client relationship where the client no longer has confidence in his attorney. F. Macknowor, supra note 115, at 77.

101 Provisions in contingent fee contracts attempting to limit the client's right to settle 
attorney may be understandably reluctant to assert these rights and to demand control of the litigation. However, this same problem exists because of the contingent fee contract itself ${ }^{162}$ and lias not been thought too great a price to pay for the advantages of such contracts.

In view of the improbability that an attorney's interest in recovering his loan would lead him to recommend an madequate settlement to his client, the danger of conflict of interest over settlement does not seem sufficiently serious to warrant disallowing loans on this ground. If an attorney does recommend such a settlement, he can and should be disciplined for taking "action whereby for his personal benefit or gain he abuses or takes advantage of the confidence reposed in him by his client."163

\section{Publicity Resulting from a Practice of Making Loans}

Even though an attorney does not seek out potential clients and offer them loans as inducements for employment, he is acting improperly if he publicizes his practice of lending money to destitute personal injury clients. Sucli conduct violates Canon 27 wlich prolibits advertising and solicitation by attorneys. ${ }^{104}$

Two recent cases, ${ }^{165}$ however, suggest that an attorney may be culpable of improper advertising if he simply loans money too often. The rationale for this view appears in a 1936 advisory opinion of the New York City Bar Association's Legal Ethics Coinmittee:

[I]t is not improper professional conduct for an attorney in sporadic instances to loan money to a client. ... However, if the attorney makes a practice of making ... loans, so that prospective clients can reasonably expect to receive the same in case they retain this particular attorney ... such conduct is professionally improper. ${ }^{168}$

If the Committee meant only that attorneys should not make a regular practice of loaning money to clients regardless of need, then its position would be supported by the "proper purpose" analysis developed in this Comment. ${ }^{167}$ However, if it meant that frequent lending by an attorney is improper despite a "proper purpose" in each individual case, then its position seems untenable.

are generally held invalid. 6A A. CoRBTr, Contracts $\$ \$ 1424-26$ (1962). See also 15 U. Det.

I.J. 146, 147 (1952).

162 F. MACKornon, supra note 115 , at 74-80, 196-98.

163 ABA Canons of Professionar Errucs No. 11, "Dealing with Trust Property."

164 See note 40 supra.

105 See notes 66-71 supra and accompanying text.

$100 \mathrm{New}$ York City Opinion 391, supra note 21, at 208.

187 See text accompanying notes 73-82 supra. 
An attorney who handles a large number of personal injury claims and who loans money to many of his clients is likely to acquire a reputation which will influence prospective clients. ${ }^{188}$ Persons with personal injury claims who are in desperate financial straits may seek to employ such an attorney because they need financial as well as legal assistance and have heard from friends or associates that he will provide both in liardslip cases. This attorney's "practice" of making loans to needy clients slrould not be considered unethical just because it brings him business.

The prolibition against advertising and solicitation in Canon 27 concerns affirmative steps taken by an attorney to advertise his services or to augment the normal publicity which results from lis accomplislments. ${ }^{169}$ Publicity which an attorney naturally receives as a byproduct of "able and effective service, whether of a professional or non-professional character . . . is entirely right and proper."170 If an attorney's lending activities are not otherwise improper, it is illogical to condemn him because they generate publicity which he has not actively sought.

To demand that an attorney must loan money only "sporadically"171 so that he will not acquire a reputation for lending and so that prospective clients will have no reason to expect loans if they retain him is tantamount to insisting that potential litigants in need of financial assistance should have no way of finding out which attorneys are likely to provide it. This makes sense only if all loans are unethical in and of themselves.

108 This is particularly true when an attorney draws many of his clients from a particular occupational group, such as railroad employees, the memhers of which are likely to communicate with each other regarding such matters as good attorneys for handling railroad accident claims. In at least two disciplinary proceedings against attorneys involving charges of improper lending to clients, the attorneys were regional counsel for the Brotherhood of Railroad Trainmen, which officially recommended them to injured railroad workers. In re Ratner, 194 Kan. 362, 399 P.2d 865 (1965); State ex rel. Beck v. Lush, 170 Neb. 376, 103 N.W.2d 136 (1960). The activities of this organization were held to he constitutionally protected in Brotherhood of R.R. Trainmen v. Virginia, 377 U.S. 1 (1964); see Bodle, Group Legal Services: The Case for BRT, 12 U.CL.A.L. Rev. 306 (1965).

It is interesting to note that many disciplinary proceedings involving cliarges of improper loans to clients were actually initiated by railroads as part of a well-financed campaign to get rid of successful plaintiffs' (railroad employees) attorneys. In re Ruffalo, $249 \mathrm{~F}$. Supp. 432, 435-37 (N.D. Ohio 1965); People ex rel. Chicago Bar Ass'n v. McCallum, 341 Ill. 578, 582, 173 N.E. 827, 828 (1930); In re Ratner, supra at 370, 399 P.2d at 872; In re Sizer, 306 Mo. 356, 363-65, 267 S.W. 922, 923-24 (1924). See generally, In re Heirich, 10 Il. 2d 357, 382-84, 140 N.E.2d 825, 837-38 (1956); State ex rel. Turner v. Denman, 36 Tenn. App. 613, 625-27, 259 S.W.2d 891, 896-97 (1952); Bodle, supra.

160 "What is wrong is for the lawyer to augment hy artificial stimulus the publicity normally resulting from what he does, seeing to it that his successes are broadcast and magnified." H. DRINKER, supra note 151, at 218.

170 Id.

171 See text accompanying note 166 supra. 
Under the "proper purpose" test they are not. If an attorney loans money to clients only for the purpose of enabling them to pursue their claims to just awards, the rule against advertising and solicitation-a rule of "professional etiquette" more than a rule of "ethics"172 _ should not be invoked against him just because he makes loans frequently and is known to do so.

\section{CONCLUSTON}

The foregoing discussion of the supposed ethical problems of loaning money for living expenses to clients to enable thein to pursue their claims suggests that the positive social value of such loans outweighs any harmful effects these loans may produce. The concern with an attorney's "purchase of an interest in litigation" seems misguided, at least when the loan is subject to repayment regardless of the outcome of the litigation. The danger of conflict of interest over settlement because of a loan is remote. One cannot logically decry the publicity resulting from large numbers of loans by an attorney unless the loans themselves are improper for other reasons.

If an attorney neglects his client's interests in seeking recovery of the amount loaned or if he affirmatively advertises his practice of making loans, he can and should be disciplined for his conduct; but he should not be precluded froin making loans at all just because he may abuse the privilege. The profession's ethical standards should sanction loans for hiving expenses which are made for the purpose of enabling indigent clients to obtam justice.

Based on the foregoing analysis of the ethical issues relating to loans for living expenses, the writer offers the following as a fair and reasonable rule governing such loans which should be included in the American Bar Association's new Code of Professional Responsibility:

If an attorney in good faith determines that a present or prospective client has a meritorious claim, he may lend or agree to lend money to such client, in an amount which does not clearly and materially exceed what the attorney in good faith believes to be the client's requirements for food, housing, medical attention and other subsistence needs, for the purpose of enabling the client to secure trial or reasonable settlement of his claim.

In no case may an attorney offer such a loan to a prospective or potential client. He may, however, upon the request of a prospective client, agree that he will loan him money if he is employed.

The attorney must demand from the client a promise, in writing, that he will repay the loan regardless of the outcome of his claim.173

172 H. DRINKER, supra note 151, at 211 n.3.

173 Effective June 1, 1967, Rule 3a of the RULes of Professtonal Conduct of the StaTE BAR of CALIFORNIA, supra note 7, was amended to provide: 


\section{- Drafter's Comments on the Proposed Rule}

$a$. The requirement that the attorney determine that the borrower's claim is meritorious is a specific apphication of the general ethical rule that an attorney should never knowingly represent a person seeking to assert a sham claim. The attorney is not precluded from representing or assisting financially a person whose claim is merely questionable. Such a person should not be demed a judicial determination of the merits of his claim on the basis of his mability to engage in litigation without financial assistance.

A good faith standard for the attorney's evaluation of a claim is preferable to a standard of reasonableness. This is a rule defining ethical conduct, and it should not be considered unethical for an attorney to make an unreasonable judgment if lie does so in good faith.

$b$. The limitation on the amount which may be loaned to a client is designed to reinforce the rule's fundamental prohibition of loans offered as inducements to potential clients (see comment $d$ ). Any loan which clearly and materially exceeds a client's subsistence needs is probably offered by the attorney as an inducement. Forbidding such loans will not deny legitimate financial assistance to litigants but it will make punishable lending which could not otherwise be shown to lave been the product of inducement.

c. Loans which are made to enable clients to pursue legitimate claims are commendable. However, the provision that loans intended for this purpose are proper is not intended to throw upon an attorney whose

A member of the State Bar shall not directly or indirectly pay or agree to pay, or represent or sanction the representation that he will pay, medical, hospital or nursing bills or other personal expenses incurred by or for a client, prospective or existing; provided this rule shall not prohibit a member:

(1) with the consent of the client, from paying or agreeing to pay to third persons such expenses from funds collected or to be collected for the client; or

(2) after he has been employed, from lending money to lis client upon the client's promise in writing to repay such loan; or

(3) from advancing the costs of prosecuting or defending a claim or action. ...

42 Cax. Sr. B. J. 192 (1967) (emphasis added). The Rule proposed in this Comment is not only more explicit but also more restrictive than the new California RuLE $3 a$ with respect to the permissible amount of a loan. It is bclieved that this restrictiveness will not only make the proposed rule more palatable to members of the bar who are hesitant to permit loans at all but will also check the improper use of loans as inducements. See text accompanying note 90 supra.

The prior California RULE 3a, dealing with an attorney's financial assistance to his clients but failing to mention loans explicitly, is found in 52 Cal. 2d 893, 896-97 (1959). See Guides to Professional Conduct for the New California Practitioner, 36 Cax. ST. B.J. 1013, 1021 (1961), for a rather unenlightening commentary on this rule. Two earlier proposed amendments of RULE 3a, which were found unacceptable by the members of the State Bar, are found in 40 CAT. Sr. B.J. 241 (1965) and 41 CAx. Sx. B.J. 350 (1966). 
lending is called into question the responsibility of showing that, but for his help, the client would have been unable to hitigate his claim or to settle it for a reasonable amount.

$d$. It is impermissible for an attorney to offer a loan to a person with whom he initiates contact (a "potential client") for the purpose of obtaining employment. Of course the existing rule against "ambulance chasing" makes any seeking out of clients unethical anyway.

It is also improper for an attorney to offer a loan to a person who has come to him inquiring about the possibility of the attorney representing him (a "prospective client"). Although this would not constitute "ambulance chasing," it would amount to solicitation. However, an attorney is not forbidden to agree, upon the request of a prospective client, that he will loan money if he is employed. This is neither "ambulance chasing" nor solicitation.

$e$. The requirement that financial assistance be given in the form of a loan rather than in the form of an advance with the obligation to repay made contingent on recovery is not only dictated by the traditional aversion to champerty held by an influential segment of the legal profession but justified by the imterest in precluding the use of loans as inducements. Contingent advances are usually offered as inducements while loans are not. Since clients would not benefit if such advances were allowed, it seems desirable to prohibit them.

William Roger Strelow 